\title{
Exploring the Issues and Challenges in Managing Themed Restaurant in Klang Valley, Malaysia
}

Farah Adibah Che Ishak, Norhabibah Mazlan, Nur Atiqah Lokman, Muhamad Shahrim Abd Karim \& Siti Fatimah Mohamad

To Link this Article: http://dx.doi.org/10.6007/IJARBSS/v11-i10/11490～DOI:10.6007/IJARBSS/v11-i10/11490

Received: 04 August 2021, Revised: 30 August 2021, Accepted: 18 September 2021

Published Online: 01 October 2021

In-Text Citation: (Ishak et al., 2021)

To Cite this Article: Ishak, F. A. C., Mazlan, N., Lokman, N. A., Karim, M. S. A., \& Mohamad, S. F. (2021). Exploring the Issues and Challenges in Managing Themed Restaurant in Klang Valley, Malaysia. International Journal of Academic Research in Business and Social Sciences, 11(10), 1121 - 1135.

Copyright: (c) 2021 The Author(s)

Published by Human Resource Management Academic Research Society (www.hrmars.com)

This article is published under the Creative Commons Attribution (CC BY 4.0) license. Anyone may reproduce, distribute, translate and create derivative works of this article (for both commercial and non-commercial purposes), subject to full attribution to the original publication and authors. The full terms of this license may be seen at: http://creativecommons.org/licences/by/4.0/legalcode

Vol. 11, No. 10, 2021, Pg. 1121 - 1135

Full Terms \& Conditions of access and use can be found at http://hrmars.com/index.php/pages/detail/publication-ethics 


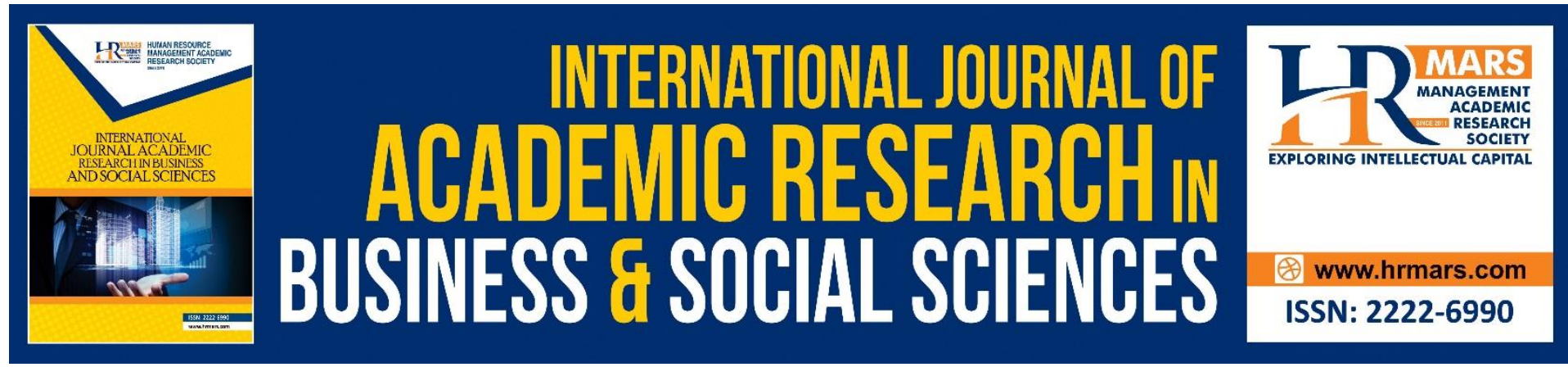

\title{
Exploring the Issues and Challenges in Managing Themed Restaurant in Klang Valley, Malaysia
}

\author{
Farah Adibah Che Ishak, Norhabibah Mazlan, Nur Atiqah \\ Lokman, Muhamad Shahrim Abd Karim \& Siti Fatimah \\ Mohamad
}

Faculty of Food and Science Technology, Universiti Putra Malaysia

Email: farahadibah@upm.edu.my

\begin{abstract}
Themed restaurant emphasizes the staging of the dining experience to attract its patrons. Its unique concept and décor excite patrons to explore new food consumption experience and make them a popular choice in the market. However, it appears that restaurants in this niche have shorter 'shelf life' due to various managerial issues that force them to close. These restaurants are also too dependent on trends and would slowly vanish when it is over. Therefore, themed restaurants are seen to have more potential problems and have a high risk of sustaining in the industry. Thus, this research aims to identify the internal issues in managing themed restaurants and explore the business operation's external challenges. A qualitative research approach was implemented through semi-structured interviews with ten managers of themed restaurants across the Klang Valley area. The interview sessions were recorded and then transcribed, coded, themed, and analyzed using thematic analysis. Results concluded that the managers' internal issues are financial, sales and marketing, design and layout, location, and staff. On the other hand, customers, competitors, price of good fluctuation, and suppliers are the external challenges in managing themed restaurants. The findings of this study contributed to the theoretical knowledge of themed restaurants within the Malaysia context and benefited the restaurant owners. It may assist the existing restaurants in improving the business strategy to overcome the challenges and maneuver the new entry owners in the beginning stage of their entrepreneurial journey.
\end{abstract}

Keywords: Themed Restaurant, Challenges, Restaurant Management, Trend, Risk

\section{Introduction}

As urbanization widens its reach across the country, people work longer hours and have less time to spend in the kitchen. This phenomenon forces people to either ordering food delivery or opted eating out more frequently (Schaefer, 2021). Relatively, this trend causing an overal change in eating patterns, which benefits the foodservice industry. According to the Department of Statistics Malaysia (2020), the timeline census reported decreasing food at home expenditure from $20.1 \%$ in 2004 to $17.3 \%$ in 2019 . Whereas, the percentage of food away from home spending rises from $8.7 \%$ to $11.2 \%$ for the same duration. This spending pattern might be due to $4.2 . \%$ increment of salary from 2016 to 2019, making the mean 
household income in Malaysia was RM7,901. As the household income increases each year, the patrons demand to explore something new in their food consumption and food experience. Thus, themed restaurant can be the answer as it is a place offering a unique concept restaurant that highlights dinescape elements through special interior design, lighting, and music (Hsu \& Powers, 2002; Thapa, 2013). Ariffin et al (2012) stated that the elements of style, lighting, and layout positively correlate with customer behavior in attitude, Words of Mouth (WoM) intention, and revisit intention. In the same vein, Mattila and Gao (2017) explained, restaurant atmospheric can increases customers' purchasing intention by designing the environment to create emotional effects.

With people eating more outside, it resulted into the foodservice industry in Malaysia become mushrooming as foodservcie establishments reported to rose from 130, 570 establishments in 2010 to 167,490 in 2017 (Department of Statistics Malaysia, 2017). However, it is hard to determine the exact number of the themed restaurant as it is not registered under one organization (Noorkhizan et al., 2012). Among the existing themed restaurants in Klang Valley are Old China Café, Dining in The Dark, DC Comic Superhero, Botanica+Co and Ahoy Café (Azman, 2019; Tay, 2015). However, despite these positive numbers in the market, many have started to close after a few years of operation. These closures include Chemistry Café \& Lab (June 2014 - February 2017), Hello Kitty Gourmet Café (Sept 2015 - July 2017), Flying Teapot Café (October 2013- May 2016) and D’Dream Doraemon Café (2014- Dec 2015). These restaurants are among the popular themed restaurants that gain popularity (Chemistry Cafe, 2018; Dream Youth Cafe, 2015; Ng, 2015, 2017; Openrice Group Inc., 2015) but only survived in the industry for two to three years of operation. Themed restaurants are also too dependent on trends and would slowly vanish when it is over. Hence, questions have been raised about the reasons why they hardly sustain in the industry. This issue is serious as the themed restaurant can be an attraction and contribute to Malaysia's economy.

Nevertheless, there may not be sufficient relevant literature discovering the challenges faced by the themed restaurant. Previous research on restaurant management challenges focuses on different types of restaurants such as independent café, hotel restaurants, casual dining restaurants, and small-medium enterprise (SME) food places. For instance, Lee, Lee, Chua, and Han (2017) discuss the challenges and critical success factors of independent restaurants in Klang Valley, which then extend their research scope to hotel restaurants. While Eravia, Handayani and Julina (2015) explore the opportunities and challenges, focusing only on the SME restaurants in Pekan Baru, Indonesia, which they conclude that information technology, human resources, and raw capital were among the challenges facing this type of restaurant. As for the themed restaurant, previous studies discuss customers' behavior towards the dinescape in themed restaurants. These include the customer revisit intention and loyalty towards themed restaurant (Meng \& Choi, 2018; Tüver, Güzel, \& Iş̧̧i, 2018; Wan Nawawi et al., 2018). As so far, little attention has been paid to managerial issues of themed restaurants, such as revenue management (Noorkhizan et al., 2012), menu management (Ozdemir \& Caliskan, 2014), service quality, perceived value and the restaurant's image (Clemes et al., 2018) as well as brand personality (Kim, Magnini \& Singal, 2011).

Thus, this study is significant in filling the gap between previous studies by collecting the new data, specifically in the scope of themed restaurants. Practically, this study provides information about theme restaurants' issues and challenges to help the current and future 
foodservice entrepreneurs incorporate the findings into their business strategies to survive in the industry.

\section{Themed Restaurant Definition}

Themed restaurant is a unique food place. Hsu and Powers (2002) described a themed restaurant as a concept restaurant designed at a particular spot or area with a distinctive building, style of music, and personality. It is a restaurant where the concept prioritizes the surrounding through emphasizing fun, fantasy, glamour, and romance, which have an instantly recognizable and easily articulable concept (Thapa, 2013). In the late nineteenth century, the first themed restaurant was Café du Bagne (Café of the Penitentiary). Maxime Lisbonne opened it in Montmartre, a Commune member who had been banished in a South Pacific penal colony for a long time. Posters on the café wall replicated a prison eating hall, hailed Commune heroes while the waiters were dressed as real convicts but with fake balls and chains (Whitaker, 2010; Waters, 2017). This shows that experience as a concept is not that new, but it is not until now that people slowly start realizing its economic value (Simpson, 2003). In other words, food and amenities only are not enough for customers nowadays (Jalil, Fikry, \& Zainuddin, 2016). Therefore, theming is commonly used as a strategy in the foodservice industry to differentiate themselves from competitors by providing customers with unique experiences (Gilmore \& Pine, 2002).

A review of the literature shows that a themed restaurant can be coined as an "eatertainment". "Eatertainment" restaurant is a fun restaurant that offers entertainment and an enjoyable experience that allows customers to experience overall satisfaction (Josiam \& Henry, 2014; Wood \& Munoz, 2007). In the same vein, Simpson (2003) also stated that entertainment restaurants provide another time, space, place, atmosphere, or environment and a memorable experience for the customers. Examples of "eatertainment" are animation restaurants, restaurants with live performances, and 3-D restaurants (Josiam \& Henry, 2014). This type of restaurant mainly attracts customers with their exciting concept instead of their food (Puspita, 2015). Likewise, ethnic-themed restaurants focused more on the authenticity of food since their restaurants purposely served the origin taste to the customers besides giving an ethnic experience through their decorations and the environments (Gai, 2014; Zhao et al., 2016).

\section{Restaurant Business Issues and Challenges}

A business operation can not hide from obstacles. Experiencing the obstacles will allow the management to learn how to react and help the business to grow. A large and growing body of literatures had investigated that challenges faced by the restaurant businesses fall into two main categories; internal and external issues. The internal or controllable issues are coming from the inside of the organization. These types of subjects are likely to impact the ability or inability of the business to meet its goals and objectives (Elimimian, Jonathan \& Edevbie, 2013). These include staffing, financial limitation, marketing, and food safety practices.

Traditionally, it has been argued that staffing is the major problem faced by restaurant management, especially in an independent restaurant. Staff turnover rate for restaurants is relatively high, about 40 to $49 \%$ in the small-scale restaurant (Batt, Lee \& Lakhani, 2014; Kaya, Bezirgan, \& Alamur, 2015). As a result, restaurants need to bear the consequences of losing talented employees, product inconsistency and decreased service quality (Adnan et al., 2018; 
Alonso \& O'Neill, 2009). When an employee leaves an organization, the company also must bear various costs to find a replacement starting with the recruitment process, training program, and the team buildings (Al Mamun \& Hasan, 2017; Atef, Leithy, \& Al-Kalyaubi, 2017). A study by Batt et al (2014) reported that the turnover cost for a restaurant with 30 employees is about $\$ 18,200$. This amount shows that employers will also face a financial issue if the turnover rate continues to rose.

The financial issue is another crucial subject in the restaurant business. According to Parsa, Self, Sydnor-Busso and Yoon (2011), about $25 \%$ to $49 \%$ of restaurants in the US fail during the first year of operation due to the lack of financial resources. This situation proved financial limitation becoming the major concern for restaurant management. Enz's (2004) crosscountry analysis shows that managing escalating costs was a key accounting issue for $71 \%$ of the managers responding to her survey. The inherent difficulties are mainly due to the nature of the restaurant business, such as low entry barriers (e.g., a small amount of required capital), the high proportion of operating expenses (e.g., food costs, labor costs, and rent expenses), and the existence of many substitutions in the market (DeFranco, Agnes \& Lattin, 2007). In the same situation, Mun and Jang (2018) find that high prime costs (food costs and salary expenses) could be a significant concern for full-service restaurant businesses and cause lower profitability. Consequently, low profitability and poor cash management will provoke them to dilute the initial concept of the restaurant to meet the essential requirement of survival (Lee et al., 2017).

In achieving good customer perception, restaurateurs need to be geniuses in marketing themselves. As for the independent restaurant, the advertising challenges appear daunting and costly in highly competitive markets, especially during difficult economic times (Enz, 2004). However, advertising expenses are beneficial for generating sales (Mun \& Jang, 2018). Advertising expenditure has been identified to significantly affect restaurant firms' intangible value, such as profitability and financial leverage (Hsu \& Shawn, 2008). In this modern era, small businesses prefer to use social media platform to form one-on-one relationships with their customers and reach new prospects (Namkung, 2018). Despite the benefits, most restaurant owners face issues in making their advertisements attractive, consistent, and actively responding to the customers (Bennett, 2017; Tanamas \& Hussain, 2012). Marketing management appears to be an issue here.

Besides, it is also an issue for restaurant managers to incorporate safe food practices into restaurants to prevent accidents or illnesses. Studies conducted in both West and East Malaysia have shown that even with adequate food safety knowledge, many Malaysian food handlers still displayed poor food safety practices (Abdul-Mutalib et al., 2012; Lim, Chye, Sulaiman, Suki, \& Lee, 2016). In an investigation into food safety practices, Mohlisi et al (2018) stated that food handlers attend the training session but lack an understanding of the knowledge taught. They further argued that food handlers are aware of the need for personal hygiene, but they do not comprehend crucial aspects linked to temperature values as needed to control microbes' growth in food.

In another perspective, it is the external challenges or uncontrollable issues that are beyond the restaurants' capabilities to control it that can impact a business's ability to achieve its 
strategic goals or objective. These challenges include the high competition in an urban area, price of good fluctuation, customer demand and satisfaction, and the location.

Several studies have examined the competition issues faced by restaurants where independent restaurant experiences 2.5 times higher failures rates compared to chain restaurants (Parsa et al., 2011). This visualizes how competitive and volatile the restaurant industry can be, with many food places closing within the first two to three years of operations (Khanfar, Loudon, \& Mujtaba, 2010; Leiper \& Stear, 2009). Population in urban areas such as the Klang Valley tend to eat out, resulting in the rapid growth of foodservice establishments (Fatimah, Boo, Sambasivan \& Salleh, 2011). The high number of international franchisees entering urbanized locations in this area, such as Kuala Lumpur, Petaling Jaya and Subang Jaya, has raised competition faced by the local independent establishments. Moreover, competition in Klang Valley is further increased by the growing number of illegal food operators that are able to function without valid licenses due to the lack of legal enforcement from the local authorities concerned (Ali \& Abdullah, 2012). Surrounded by numerous types of restaurants in a strategic place increases the challenges for current restaurants to stay unique in their own theming to be attractive and appealing to the customers' eyes (Walker, 2017).

Apart from that, independent restaurants noted the challenges of surviving because of rising costs and an inability to raise prices (Enz, 2004). In Malaysia, the trend of weak ringgit against the US dollar increases the prices of imported raw materials, which raise the direct and indirect food cost (Saari, 2017; Umi Zakiah Norazman, Haniza Khalid, \& Gairuzazmi Mat Ghani, 2018). A lot of raw food is imported from abroad such as milk, corn sugar and wheat due to the insufficient food supply (Norazman et al., 2018). In 2016, Malaysia's food import bill reached RM 15.4 billion, mainly for sugar, vegetables, fruits, cocoa, dairy products, and cereals for human consumption and animal feed production (MIDA, 2016). Consequently, restaurants must bear the rise of imported materials, forcing them to increase their menu price to ensure profitability. However, the initiative to increase the menu prices without noticeable improvement in customers' perceptions of food quality will decrease the sales and deteriorate operation performances (Min \& Min, 2011).

Several studies also indicated that the restaurant's primary challenge is to gain customer loyalty. To gain customer loyalty, restaurateurs need to know customer preferences or demands in the food industry. Nevertheless, consumer preference will continue to evolve, and it is a challenge for the restaurant industry to keep updated with the demand. According to Nicolopoulus (2018), customers nowadays prefer the bold and exotic flavor as well as the healthy menu option in their food consumption. He further states that the food companies which do not follow the trend resulting in declining in sales.

On the other hand, it is also a challenge to estimate and fulfill customer expectations. When purchasing a product or using a service, customers have expectations about the perceived value or benefits they will receive (MBA Skool, 2019). Enz (2004) examines that keeping up with customers' expectations about their restaurant is taken into actions by many managers since customers continue to demand novel, inexpensive, and intriguing food offerings. She further elaborates that some managers felt that customers' expectations had become unreasonable, while others argued that managers need a better understanding of 
demographic trends to help overcome the sales-management challenge. Achieving customer expectations will lead to customer satisfaction. However, it is difficult to know whether the customers are satisfied with the product or services offered. Thus, ensuring customer satisfaction is not an easy task and many things needed to be taken into consideration (Maharjan \& Khadka, 2017). According to Kandampully, Zhang, and Bilgihan (2015), it is important to maximize customer satisfaction as it can lead to customer loyalty.

Finding a suitable restaurant location could also be another issue for all restaurants at the business's entry stage. Location is often regarded as an uncontrollable element in the competitive environment, thus making it an external factor (Kotler et al., 2018). Lee et al. (2017) point out that difficulty in location selection is due to rising rental costs caused by the continuous appreciation of property prices. They also elaborate that high traffic volumes near the bank do not guarantee a large audience as it makes the actual customers difficult to access the parking space due to bank-goers. This view is supported by Robson (2011) and Walker (2017), who claim that important aspects of a good restaurant's site include parking availability, accessibility by employees and customers, sufficient traffic volume and the visibility of the café establishment. The convenience factors of parking such as safety and availability, are essential towards customer satisfaction that will result in customer revisit intention (Saber et al., 2017)

\section{Methodology}

This study applied a qualitative research approach with a phenomenological research design to explore the issues and challenges in managing theme restaurants in Klang Valley, Malaysia. A purposive sampling plan was applied by identifying and selecting individuals with high knowledge or experiencing the phenomenon chosen (Creswell and Clark, 2011). The data reached its saturation point through information from ten informants. This is supported by Creswell (2014), who stated that phenomenological research's sample size typically ranges from three to ten participants, while Morse (1994) suggested at least six participants for the same type of study. This study employed semi-structured interviews with the restaurant managers and owners to explore and understand the issues and challenges they faced in managing a themed restaurant. Participant observation on themed restaurants was also carried out to support the data and enrich the study's findings. The researcher used ATLAS.ti to organize the data to develop the codes and themes since it is more convenient for the data interpretation process. Thematic analysis was used in this process to bring the meaning out of the data.

\section{Results and Discussions}

This section discussed the result gained from the data analysis which based on the two objectives of the paper, namely; (1) identify the internal issues in managing themed restaurants and; (2) explore the business operation's external challenges.

\section{Internal Issues in Managing Themed Restaurant}

The analysis highlights a few internal issues in managing themed restaurants. These issues include financial obligation, marketing, design and layout, and staffing matters. From the result, the themed restaurants face elevated start-up costs and high operating costs, which lead to a severe financial issue. According to Khor (2015), investing in a cafe business will cost at least RM500,000 to RM600,000 to cover the location rental, deposit, labor costs, 
equipment and supplies. Relatively, the start-up cost for the restaurants in this study ranges between RM100, 000 to RM3 million with the break even duration around one to five years. Based on observation and interview, the themed restaurants that spend below RM 200000 appear to have a small section for theming and used recycle items for decoration; thus, it reduces the start-up cost and break-even duration.

However, themed restaurants that spent around RM1 to 2 million for the start-up, resulting in extended break-even duration. This is mainly because they want to create an environment that meets their restaurant concept and theme, causing them to allocate high expenses in interior design. This is parallel with previous studies that accentuate that themed restaurant is a restaurant where the concept takes priority over everything else, by emphasizing the designs, style music, food, and every detail of the restaurant (Hsu \& Power, 2002; Puspita, 2015).

"Set up restaurant [cost]? Exactly, I am not sure because I just take over [this restaurant]. What I know is it is about RM2-3 million." (14)

"To cover the set-up cost, any business needs 3-5 years for them to cover whatever that they spend." (I7)

In addition, informants also raised their concerns on sales and marketing issues. The finding shows that the managerial teams are struggling in conducting marketing strategies for the restaurants. Social media will be their primary platform to advertise their restaurants. Restaurants prefer to use social media as the e-WOM is efficient and fast (Namkung, 2018; Tanamas \& Hussain, 2012).

"We have tried engage someone who expert in marketing, but they didn't meet up our expectation, so we are still looking for some good team to do promotion for us." (13)

In a contradicting view, the layout of the restaurant also could give a disadvantage to the business. Themed restaurant with an outdoor dining area that highlights the chill and relaxes concept will be likely affected by the weather. The rainy season will be a challenge as the rain will reduce the spaces that can accommodate customers, hence decreasing the profit for that particular period. Walker (2017) agrees that a restaurant's challenge is to create a concept that fits a definite target market and keeps it consistent.

"If it's raining, we must close that side [outdoor dining area], this side still running but if the wind is strong, this part will be affected too. This shutter already fell because of the strong wind the previous day." (I3)
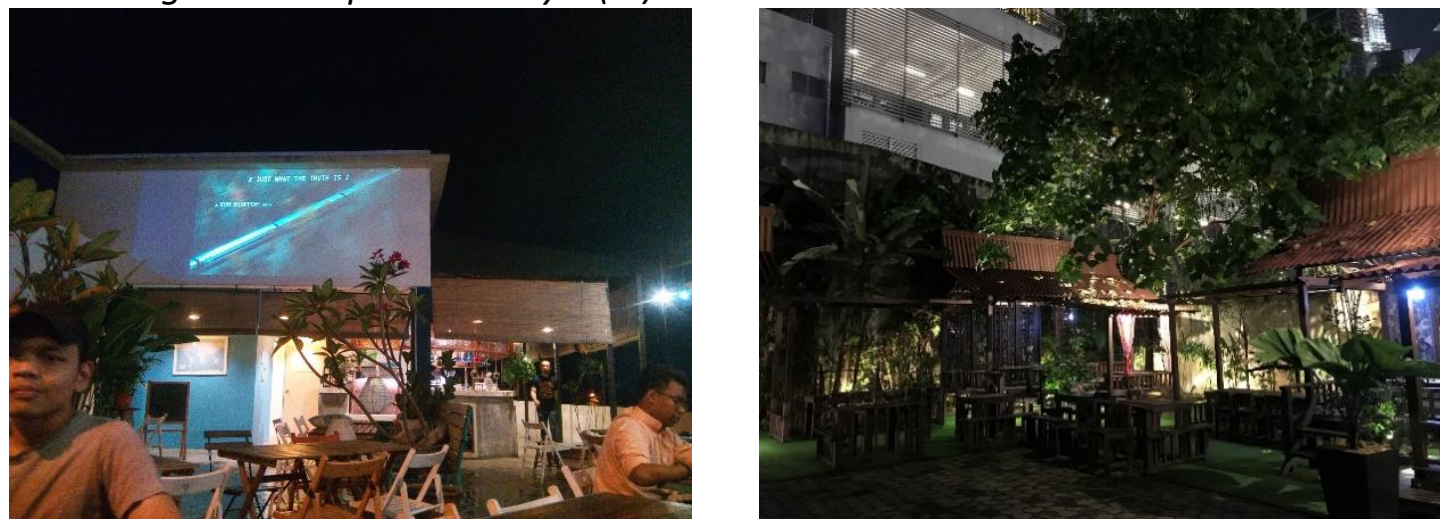

Figure 1 Outdoor dining area of themed restaurant (Author copy, 2020)

Moreover, a mutual view amongst informants is the staff issue which is seen as a major concern. This includes the high staff turnover rate, local employment difficulty, negative behaviour, lack of service skills, and foreign staff issues. Informants indicate that high 
turnover affects the business productivity. Previous studies also stated that high turnover is a significant problem and restaurant needs to bear the consequences of losing talented employees, product inconsistency and quality of service (Adnan et al., 2018; Alonso \& O'Neill, 2009). To conclude, staff issue is the primary concern in the themed restaurant and all foodservice industry (Adnan et al., 2018; Alonso \& O'Neill, 2009; Bufquin, DiPietro, Orlowski, \& Partlow, 2018).

"We need to be ready with everything like suddenly staff wants to resign, we have to take the new staff. To train new staff is quite difficult. When we already have staffs who are good at work, they suddenly get a new offer with a high salary... Then we have to train new staff but we don't get the same result as the previous staff." (I6)

\section{External Challenges in Managing Themed Restaurant}

Findings revealed that understanding customers' behavior is the most challenging part of a themed restaurant. As the themed restaurant has a picturesque concept, a lot of customers wanted to hold memorable events. However, most customers always demand the grand event and expect the perceived high quality of service with the low price before they dine in the restaurant. Enz (2004) also agrees that customers continue to demand novelty yet inexpensive products and services, causing difficulties for restaurant managers to follow customer expectations. As an example, 17 states that despite offering a luxurious floral concept, the customers still feel reluctant to pay the rental fee to close the operation for their private event.

"There are also customers who want luxurious service but they hardly to pay... In terms of rental, every private event has a rental. The standard is RM2, 500. They complaint that they still have to pay for the rental charge even they already dine there." (I7)

The following challenge faced by the themed restaurant management is the price of goods fluctuation. Consequently, they must increase their menu price or, worse, change their menu to cover the food cost. Previous studies indicated that the depreciation of the ringgit could inhibit imported inflation for Malaysia which directly and indirectly increases the cost of food (Saari, 2017; Norazman et al., 2018). However, increasing the menu price without noticeable improvement will turn down customer perception and decrease sales (Min \& Min, 2011).

"Of course, the price of goods will give us a problem. As an example, our food price is

$R M 15$, but the cost of goods is already close to RM 10 and then service charge must be included in our food costing. But we cannot simply change our menu." (I6)

On the other hand, location and its surroundings do affect the business operation. Themed restaurants in high volume traffic face several parking issues such as high parking rates and less parking availability. They complain that parking issues causing their customers reluctant to visit their restaurants. The convenience factor of parking such as safety and availability are important towards customer satisfaction, resulting in customer revisit intention (Saber et al., 2017).

"Even though this is the main road but [customer] cannot park. There is no parking [space]. Because it's the main road, authorities always come and sue... The nearest parking is at the hotel or back road." (14)

"Parking is so hard and too expensive in Taman Tun. That's why people are not interested in coming. So, we got a problem." (15) 
On top of that, the competitor is another challenge that the restaurants have to face. Even informants feel positive and confident with their uniqueness, the rising competitors affect them in a way. The urbanization of a place such as Klang Valley has greatly increased the population's tendency to eat out on a daily basis which has prompted many food operators, both legal and illegal food service establishments, to enter the industry and fight for these opportunities (Ali \& Abdullah, 2012; Fatimah et al., 2011).

"We are newly open, so the challenge is to introduce our café. This is because, in Taman Tun, there is a lot of well-known café such as Dotty, Saigon, they have their own customers. And then, in term to compete with price." (I5)

"It's more challenging now compared to 8 years ago due to lack of competitors. Back then, there is only this row, others still not exist. So, it's easier back then but now it's more challenging. You have to keep up date and compete with the newcomers." (19)

Finally, the supplier is also a part of the external challenges faced by the informants. With the high cost of charge and services, these issues would always be the concern for owners or managers. This would reduce the profit of the restaurant and need to be controlled wisely. To add, the inappropriate time for delivery such as too early, late and during the restaurant's peak hours, it will give managers a challenge to inspect the items carefully. Stockout and late of delivery maybe cannot be controlled directly by the buyer; however, if it happens frequently, manager should stop buying from that supplier (Wiley \& Inc, 2012).

"We had to use the supplier back then. When we investigate the price, it is too expensive. If it is about 20 to 30 cents, we still can consider it. But the difference is about RM 2-3 for each item. The order is about 100 items. So, the total? Costing can be affected [this way]." (16)

"Yes, we are facing issue sometimes in their delivery, their schedule. Sometimes they late. Let's say you sell these kind of fish balls but supplier doesn't have the stock for 2 months. You have to find other fish balls." (I8)

\section{Conclusions}

The study aims to identify the internal issues in managing themed restaurant and explore the external challenges of the business operation. In summary, managers' internal issues are financial, sales and marketing, design, and layout of restaurant and staff. On the other hand, customers, price of good fluctuation, location, competitors, and suppliers are the external challenges in managing themed restaurant. The results of this study provide an insight into the issues and challenges in managing themed restaurants. This research fulfills the gap of studies by exposing the managerial problems of themed restaurant's operations. By understanding the issues and challenges, the existing themed restaurant will strategize their business to overcome the challenges. The future foodservice entrepreneurs will be aware of the risks and be ready to plan the business strategy. As for future research, it is recommended to explore more themed restaurants in each area of Klang Valley to get the full context of the issue and challenges faced by this industry. Apart from that, future studies can also investigate the critical factor of success in themed restaurants. The possibility of duplicating this study's research design in different areas in Malaysia is also suggested, contributing to the overall Malaysia themed restaurant industry.

\section{Acknowledgement}

The authors wish to thank Universiti Putra Malaysia for the financial support under the Putra Young Initiative Grant (GP-IPM) [Vote no: 9673900]. 


\section{References}

Abdul-Mutalib, N. A., Abdul-Rashid, M. F., Mustafa, S., Amin-Nordin, S., Hamat, R. A., \& Osman, M. (2012). Knowledge, attitude and practices regarding food hygiene and sanitation of food handlers in Kuala Pilah, Malaysia. Food Control, 27(2), 289-293. https://doi.org/10.1016/j.foodcont.2012.04.001

Adnan, A. M., Esa, A., Rahman, A., Ahmad, R., Adnan, A. M., Esa, A., ... Ahmad, R. (2018). Factors Influencing Turnover Intention among Fast Food Restaurant Managers Factors Influencing Turnover Intention among Fast Food Restaurant Managers. International Journal of Academic Research in Business and Social Sciences, 8(17), 195-210. https://doi.org/10.6007/IJARBSS/v8-i17/5225

Ali, N., \& Abdullah, M. A. (2012). The food consumption and eating behaviour of Malaysian urbanites : Issues and concerns. Malaysia Journal of Society and Space, 8(6), 157-165.

Al Mamun, C. A., \& Hasan, M. N. (2017). Factors affecting employee turnover and sound retention strategies in business organization: A conceptual view " Factors affecting employee turnover and sound retention. Problems and Perspectives in Management, 15(April), 63-71. https://doi.org/10.21511/ppm.15(1).2017.06

Alonso, A. D., \& O'Neill, M. A. (2009). Staffing issues among small hospitality businesses: A college town case. International Journal of Hospitality Management, 28(4), 573-578. https://doi.org/10.1016/j.ijhm.2009.03.004

Ariffin, H. F., Bibon, M. F., \& Raja Abdullah, R. (2012). Restaurant's Atmospheric Elements: What The Customer Wants. Procedia - Social and Behavioral Sciences 38, 380-387

Atef, G., Leithy, W. El, \& Al-Kalyaubi, M. (2017). Factors Affecting Employee's Turnover Intention. Medwell Journal, Vol. 11, pp. 118-130. Retrieved from http://docsdrive.com/pdfs/medwelljournals/ibm/2017/118-130.pdf

Batt, R., Lee, J. E., \& Lakhani, T. (2014). A National Study of Human Resource Practices, Turnover, and Customer Service in the Restaurant Industry. 1-32.

Bennett, T. (2017). Marketing Strategies : How Small Restaurant Businesses use Social Media. Walden Dissertations and Doctoral Studies Collection.

Bufquin, D., DiPietro, R., Orlowski, M., \& Partlow, C. (2018). Social evaluations of restaurant managers: The effects on frontline employees' job attitudes and turnover intentions. International Journal of Contemporary Hospitality Management, 30(3), 1827-1844. https://doi.org/10.1108/IJCHM-11-2016-0617

Chemistry Cafe. (2018). Chemistry Café+Lab. Retrieved May 31, 2019, from Facebook website: https://www.facebook.com/chemistrycafe/

Clemes, M. D., Mohi, Z., Li, X., \& Hu, B. (2018). Synthesizing moderate upscale restaurant patrons' dining experiences. Asia Pacific Journal of Marketing and Logistics, 30(3), 627651.

Cresswell, J. W. (2014). Research Design. SAGE Publication Inc.

Creswell, J. W., \& Clark, V. L. (2011). Designing and Conducting Mixed Methods Research (2 ed.). Los Angeles: Sage Publication.

Department of Statistic Malaysia. (2020). Household expenditure survey report 2019. Malaysia: Department Of Statistics Malaysia.

Department Of Statistics Malaysia. (2017). REPORT ON HOUSEHOLD EXPENDITURE SURVEY 2016. Malaysia: Department Of Statistics Malaysia.

Department Of Statistics Malaysia. (2018). SALARIES \& WAGES SURVEY REPORT, MALAYSIA, 2017. Malaysia: Department Of Statistics Malaysia. 
DeFranco, A. L., \& Lattin, T. W. (2007). Hospitality Financial Management. In John Wiley \& Sons Inc.

Dream Youth Cafe. (2015). D’Dream 又多一梦. Retrieved May 31, 2019, from Facebook website: https://www.facebook.com/DreamYouthCafe2014/

Elimimian, Jonathan U., Edevbie, N. (2013). Issues Management: Managerial Tools for Effective Strategic Planning and Implementation Jonathan U . Elimimian Albany State University Manager Operational Definitions of Terms Used in the Paper : International Journal of Humanities and Social Science, 3(15), 34-39.

Enz, C. A. (2004). Issues of concern for restaurant owners and managers. Cornell Hotel and Restaurant Administration Quarterly, 45(4), 315-332. https://doi.org/10.1177/0010880404270065

Eravia, D., Handayani, T., \& Julina. (2015). The Opportunities and Threats of Small and Medium Enterprises in Pekanbaru: Comparison between SMEs in Food and Restaurant Industries. Procedia - Social and Behavioral Sciences, 169(August 2014), 88-97. https://doi.org/10.1016/j.sbspro.2015.01.289

Gai, L. (2014). Dining at ethnic-themed restaurants: An investigation of consumers' ethnic experiences, preference formation, and patronage. [Unpublished doctoral dissertation]. University of North https://digital.library.unt.edu/ark:/67531/metadc699898/

Gilmore, J. H., \& Pine II, B. J. (2002). Differentiating hospitality operations via experiences: why selling services is not enough. Cornell Hotel and Restaurant Administration Quarterly.43 (3), 87-96.

Hsu, C. C., \& Powers, T. (2002). Marketing Hospitality, 3rd Edition. John Wiley and Sons Inc

Hsu, L. J., \& Shawn, S. (2008). Advertising expenditure, intangible value and risk : A study of restaurant companies. International Journal of Hospitality Management, 27(July 2003), 259-267. https://doi.org/10.1016/j.ijhm.2007.07.012

Jalil, N. A. A., Fikry, A., \& Zainuddin, A. (2016). E-Atmospheric Effects on Youth Intention to Revisit a Cafe. Procedia Economics and Finance, 37(December), 497-503. https://doi.org/10.1016/s2212-5671(16)30157-5

Feinstein, A., Hertzman, J. \& Stefanelli, J. M. (2017). Purchasing Selection and Procurement For Hospitality Industry (8th ed.). John Wiley \& Sons, Inc.

Josiam, B. M., \& Henry, W. (2014). Eatertainment: Utilitarian and Hedonic Motivations for Patronizing Fun Experience Restaurants. Procedia - Social and Behavioral Sciences, 144, 187-202. https://doi.org/10.1016/j.sbspro.2014.07.287

Kaya, İ., Bezirgan, M., \& Alamur, B. (2015). Minimum Turnover Analysis in Turkish Tourism Sector. Procedia - Social and Behavioral Sciences, 207, 404-413.

https://doi.org/10.1016/j.sbspro.2015.10.110

Kandampully, J., Zhang, T. (Christina), \& Bilgihan, A. (2015). Customer loyalty: A review and future directions with a special focus on the hospitality industry. International Journal of Contemporary Hospitality Management, 27(3), 379-414. https://doi.org/10.1108/IJCHM-03-2014-0151

Khanfar, N. M., Loudon, D., \& Mujtaba, B. G. (2010). Santorini Restaurant: One Entrepreneur's Start-Up Adventure. Journal of Business Studies Quarterly, 1(2), 70-74.

Khairul Azman, K. (2019). 7 Aesthetically Pleasing Nature-Themed Restaurants \&amp; Cafes In Klang Valley. Retrieved May 31, 2019, from Says.com website: https://says.com/my/makan/7-nature-themed-restaurants-cafes-klang-valley

Khor, S. (2015). If You 've Ever Thought Of Owning A Cafe, These 8 Realities Might Make You 
Think Twice. Says Lifestyle. Retrieved from https://says.com/my/lifestyle/if-you-veever-thought-of-owning-a-cafe-these-8-realities-might-make-you-think-twice

Kim, D., Magnini, V. P., \& Singal, M. (2011). The effects of customers' perceptions of brand personality in casual theme restaurants. International Journal of Hospitality Management, 30, 448-458.

Kotler, P., Keller, K. L., Ang, S.-H., Tan, C.-T., \& Leong, S. M. (2018). Marketing Management, An Asian Perspective. Retrieved from https://www.worldcat.org/title/marketingmanagement-an-asian-perspective/oclc/1023552002

Lee, S., Lee, K., Chua, B., \& Han, H. (2017). Independent café entrepreneurships in Klang Valley , Malaysia - Challenges and critical factors for success : Does family matter ? Journal of Destination Marketing \& Management Independent café entrepreneurships in Klang Valley, Malaysia - Challenges and. Journal of Destination Marketing \& Management, 6(4), 363-374. https://doi.org/10.1016/j.jdmm.2016.05.002

Leiper, N., \& Stear, L. (2009). Tourism-related business failures: The case of the Spice Islands Restaurant. Journal of Vacation Marketing, 15(4), 367-380.

https://doi.org/10.1177/1356766709335836

Lim, T. P., Chye, F. Y., Sulaiman, M. R., Suki, N. M., \& Lee, J. S. (2016). A structural modeling on food safety knowledge, attitude, and behaviour among Bum Bum Island community of Semporna, Sabah. Food Control, 60, 241-246.

https://doi.org/10.1016/j.foodcont.2015.07.042

Maharjan, S., \& Khadka, K. (2017). Customer Satisfaction and Customer Loyalty. Customer Satisfaction and Customer Loyalty, (November), 58+6. Retrieved from https://www.scribd.com/document/393361416/Customer-Satisfaction-and-

Customer-Loyalty

Mattila, A. S., \& Gao, L. (. (2017). Atmospherics and the touristic experience. Design Science in Tourism, 151-160.

MBA Skool. (2019). Customer Expectations Definition in Marketing Dictionary. Retrieved May 30, 2019, from https://www.mbaskool.com/business-concepts/marketing-andstrategy-terms/11513-customer-expectations.html

Meng, B., \& Choi, K. (2018). An investigation on customer revisit intention to theme restaurants. International Journal of Contemporary Hospitality Management, 30(3), 1646-1662. https://doi.org/10.1108/ijchm-11-2016-0630

Malaysian Investment Development Authority (MIDA). (1 June, 2018). Hospitality. Retrieved from Malaysian Investment Development Authority: http://www.mida.gov.my/home/hospitality/posts/

Min, H., \& Min, H. (2011). Benchmarking the service quality of fast-food restaurant franchises in the USA: A longitudinal study. Benchmarking, 18(2), 282-300. https://doi.org/10.1108/14635771111121711

Mohlisi, U., Asmawi, M., Norehan, A. A., Salikin, K., Ain, N., Rosdi, S., ... Nor, N. (2018). Current Research in Nutrition and Food Science An Assessment of Knowledge, Attitudes and Practices in Food Safety Among Food Handlers Engaged in Food Courts. 06(2), 0-7.

Morse, J. M. (1994). Determining Sample Size. Qualitative Health Research 10(1), 3-5.

Mun, S. G., \& Jang, S. C. (Shawn). (2018). Restaurant operating expenses and their effects on profitability enhancement. International Journal of Hospitality Management, 71(September 2016), 68-76. https://doi.org/10.1016/j.ijhm.2017.12.002

Namkung, K. L. (2018). The impact of restaurant patrons' flow experience on SNS satisfaction and offline purchase intentions. International Journal of Contemporary Hospitality 
Management, 30(2), 797-816.

Ng, W. (2015). Hello Kitty Gourmet Café Sunway Pyramid. Retrieved May 31, 2019, from Family Food and Travel Blog website: https://www.placesandfoods.com/2015/09/hello-kitty-gourmet-cafe-sunwaypyramid.html

Ng, W. (2017). Hello Kitty Gourmet Café Malaysia Officially Closed Down. Retrieved May 31, 2019, from Family Food and Travel Blog website: https://www.placesandfoods.com/2017/07/hello-kitty-gourmet-cafe-malaysiaofficially-closed.html

Nicolopoulus, J. (2018). Top 5 trends for food and beverage industry businesses in 2018 (Video) - Boston Business Journal. Retrieved May 27, 2019, from Boston Business Journal website: https://www.bizjournals.com/boston/news/2018/01/29/top-5trends-for-food-and-beverage-industry.html

Noorkhizan, M., Radzi, S., Abdullah, F., \& Adzel, A. (2012). Revenue Management Practices and Restaurant Performance: A Study on Theme Restaurants in Klang Valley, Malaysia. Current Issues In Hospitality and Tourism Research and Innovations, 117-120.

Openrice Group Inc. (2015). Dreams are made of Cotton Candies at These Themed Cafes in Klang Valley! Retrieved May 31, 2019, from Open Rice Web website: https://my.openrice.com/en/klangvalley/article/dreams-are-made-of-cotton-candiesat-these-themed-cafes-in-klang-valley-a1042

Parsa, H. G., Self, J., Sydnor-Busso, S., \& Yoon, H. J. (2011). Why Restaurants Fail? Part II - The Impact of Affiliation, Location, and Size on Restaurant Failures: Results from a Survival Analysis. Journal of Foodservice Business Research, 14(4), 360-379. https://doi.org/10.1080/15378020.2011.625824

Puspita. (2015). Physical Evidence of Small Theme Restaurant in Indonesia: A Case Study of Ramen House. Procedia-Social and Behavioral Science, 169, 289-295.

Robson, S. (2011). That 's the Spot ! Strategies for Finding the Ideal Restaurant Site That 's the Spot ! Strategies for Finding the Ideal Restaurant Site. 8, 24-29.

Ozdemir, B., \& Caliskan, O. (2014) A review of literature on restaurant menus: Specifying the managerial issues. International Journal of Gastronomy and Food Science, 2(1), 3-13

Saari. (2017). Cost of Living expected to continue soaring in 2017 Faculty of Economics and Management , Universiti Putra Malaysia Email: Retrieved from https://www.upm.edu.my/artikel/kos_sara_hidup_dijangka_terus_meningkat_tahun_ 2017-30199?L=en

Saber, J. M., Ibrahim, M. Z. F., Mustapha, R. I. P. R., Salim, A., Sandikau, E. N. R., \& Lajis, N. A. A. (2017). The Effects of Parking Convenience Towards Customer Retention in Gurney Drive, Penang : A Preliminary Study. International Academic Research Journal of Social Science, 3(1), 1-5.

Schaefer, M. (2021). Five trends drivivng the era of food on demand. Retrieved September 1, 2021, from the euromonitor website: https://www.euromonitor.com/article/fivetrends-driving-the-era-of-food-on-demand

Simpson, R. J. (2003). Theme and Experience in Restaurant Design: A Theory. [Unpublished Master dissertation]. Washington State University.

Tanamas, P., \& Hussain, K. (2012). Online Marketing Opportunities and Challenges for Restaurants. 9(1), 39-53.

Tay, K. (2015). 10 Themed Restaurants In Malaysia For A Dining Experience Like No Other. Retrieved May 31, 2019, from The Smart Local Singapore website: 
https://thesmartlocal.com/read/themed-restaurants-malaysia

Thapa, B. (2013). Themed restaurant. Retrieved from Linkedln Slide Share: https://www.slideshare.net/binoythapachetri/themed-restaurant

Tüver, I. F., Güzel, B., \& Işçi, C. (2018). Dinescape Factors Affecting the Satisfaction and Loyalty of Fish Restaurant Customers. Journal of Tourism and Gastronomy Studies, 6(2), 4-22. https://doi.org/10.21325/jotags.2018.199

Wan Nawawi, W. N., Wan Kamarudin, W. N. B., Mat Ghani, A., \& Adnan, A. M. (2018). Influence of Theme Restaurant Atmospheric Factors Towards Customers' Revisit Intention. Environment-Behaviour Proceedings Journal, 3(7), 0-6. https://doi.org/10.21834/e-bpj.v3i7.1231

Walker, J. R. (2017). Restaurant Concepts, Management, and Operations $8^{\text {th }}$ ed. Wiley.

Waters, M. (2017). Stories: Old Hollywood's Best Theme Restaurants Specialized in Abductions and Dungeons. Retrieved from Atlas Obscura:

https://www.atlasobscura.com/articles/los-angeles-theme-restaurants-jail-cafepirates-den

Whitaker, J. (2010). Birth of the theme restaurant. Retrieved from Restaurant-ing through history: https://restaurant-ingthroughhistory.com/2010/04/01/birth-of-the-themerestaurant/

Zhao, S., Scott, K., Johnson, E., \& Johnston, E. (2016). Experiencing 'Otherness ' in EthnicThemed Restaurants. 